KOŚCIÓŁ I PRAWO 9(22) 2020, nr 2, s. 49-68

DOI: http://dx.doi.org/10.18290/kip2092-4

\author{
Karol Mafa-Karliński
}

\title{
OBRONA RODZINY \\ W KODEKSIE PRAWA KANONICZNEGO \\ Z 1983 ROKU
}

Rodzina jest podstawową komórką społeczeństwa i Kościoła. Zgodnie z Katechizmem Kościoła Katolickiego ${ }^{1}$ „mężczyzna i kobieta połączeni małżeństwem tworzą ze swoimi dziećmi rodzinę" (nr 2202), która jest wspólnotą miłości dążącą do świętości. W niniejszym artykule zostanie podjęta próba ukazania obrony i umocnienia instytucji rodziny w prawodawstwie kościelnym, a zwłaszcza w Kodeksie Prawa Kanonicznego z 1983 r. ${ }^{2}$ Dlatego też $\mathrm{w}$ pierwszej kolejności należy przypomnieć wybrane podstawowe prawdy na temat rodziny zawarte w Biblii i rozważane przez Sobór Watykański II, a także wybrane dokumenty Kościoła. Wydaje się, że instytucja rodziny $\mathrm{w}$ ostatnich miesiącach znów doświadcza wzmożonych ataków, których celem jest podważenie i zniszczenie jej kształtu zamierzonego i nadanego przez Stwórcę.

MGR LIC. KAROL MAFA-KARLIŃSKI, DOKTORANT - Wydział Teologiczny, Uniwersytet Papieski Jana Pawła II w Krakowie; e-mail: karlinskikarol@gmail.com; https://orcid. org/0000-0002-1549-5718

${ }^{1}$ Catechismus Catholicae Ecclesiae, Libreria Editrice Vaticana, Città del Vaticano 1997; tekst polski: Katechizm Kościoła Katolickiego, Pallottinum, Poznań 2002.

${ }^{2}$ Codex Iuris Canonici auctoritate Ioannis Pauli PP. II promulgatus (25.01.1983), AAS 75 (1983), pars II, s. 1-317; tekst polski: Kodeks Prawa Kanonicznego, przekład polski zatwierdzony przez Konferencję Episkopatu, Pallottinum, Poznań 1984 [dalej cyt.: KPK/83]. 


\section{ZARYS PROBLEMATYKI RODZINY W BIBLII}

Teologia katolicka mówiąc o złożonej problematyce rodzinnej bazuje przede wszystkim na Objawieniu. W Biblii nie ma syntetycznej definicji rodziny, ale jest ona ukazana jako naturalna instytucja, bezpośrednio zamierzona i zakorzeniona w odwiecznym planie Stwórcy, która ma jedną z najważniejszych ról w kształtowaniu społeczeństwa [Jelonek 2007, 7].

Należy dostrzec, że inaczej rozłożone są akcenty dotyczące rodziny w Starym Testamencie, a inaczej w Nowym Testamencie: najpierw silnie zarysowana jest rola rodziny w kształtowaniu się narodu izraelskiego, prawa i przekazywaniu tradycji religijnych, a następnie Jezus pokazuje rodzinę, jako drogę uświęcenia oraz podkreśla jej nierozerwalność i sakramentalność.

Teokratyczna prawda o stworzeniu człowieka jako arcydzieła Boga została ukazana w dwóch opisach według tradycji: kapłańskiej (Rdz 1,1-2,4a) i jahwistycznej (Rdz 2,4b-25) [Pawlak 2001, 65-74]. Biblia opisując akt stworzenia świata wskazuje, że człowiek jest koroną stworzenia, gdyż „Bóg stworzył człowieka na swój obraz, na obraz Boży go stworzył: stworzył mężczyznę i niewiastę" (Rdz 1,27$)^{3}$. Pismo Święte podkreśla godność człowieka i wskazuje, że jego natura czyni go podmiotem różnych praw i obowiązków stanowiących jednocześnie zadania, jakie ludzie będą realizować w życiu. Te prawa zakorzenione są w wolności ludzkiej, w tym również w swobodzie decydowania o sobie samym, o swojej niezależności czy o założeniu rodziny [Jelonek 2011, 211-13].

Bóg powołując do istnienia człowieka, uczynił go jednocześnie współuczestnikiem przekazywania życia oraz jego obrońcą: „bądźcie płodni i rozmnażajcie się, abyście zaludnili ziemię i uczynili ją sobie poddaną” (Rdz 1,28). Rodzina w tym ujęciu nie jest instytucją tylko ludzką, ale również Boską. Zamierzone bezpośrednio przez Stwórcę odmienność płci i ich komplementarność sprawiają, że mężczyzna i kobieta stworzeni są dla siebie, by tworzyć trwałą jedność [Białkowska 2010].

Drugi opis stworzenia człowieka podkreśla dwoistość natury ludzkiej: „tchnął w jego nozdrza tchnienie życia, wskutek czego stał się człowiek istotą żywą” ( $R d z$ 2,7). Poprzez wyrażenie: „być obrazem Boga” należy

\footnotetext{
${ }^{3}$ Pismo Święte Starego i Nowego Testamentu w przekładzie z języków oryginalnych, wyd. 5, Pallottinum, Poznań 2000.
} 
rozumieć m.in. to, że człowiek posiada duszę, rozum i wolną wolę, co daje ogromne możliwości, prawdziwą wolność, ale również jest szczególnym wezwaniem do miłości i troski o życie, gdyż Bóg jest miłością oraz Dawcą życia. Pomimo tego, że ludzie zostali obdarowani wolnością, to Bóg dał człowiekowi pewne normy postępowania, przez co ludzie stali się istotami etycznymi [Stachowiak 1990, 91-99]. Ponadto Bóg nakazał ludziom panować nad zwierzętami i uczynić sobie ziemię poddaną (Rdz 1,26), co wskazuje, że człowiek jest powołany do pracy [Jelonek 2007, 44].

Skażenie ludzkiej natury grzechem pierworodnym ma swoje implikacje w małżeństwie i rodzinie, np. w Biblii znajdujemy możliwość rozwodu w przypadku, gdy mąż „nie będzie darzył jej [żony] życzliwością, gdyż znalazł u niej coś odrażającego, to napisze jej list rozwodowy, wręczy go jej, potem odeśle ją od siebie" (Ptw 24,1). Innym zagrożeniem dla rodziny jest cudzołóstwo, którego zakazuje m.in. Dekalog (Wj 20,14) [Pawlak 2001, 65-74].

W Księdze Kapłańskiej znajdujemy jedne z pierwszych przepisów broniących rodzinę, które są bardzo ostre i jednoznaczne, nakazują szacunek i cześć wobec rodziców, zakazują zdrad i rozpusty (Kpł 20,9-12). Już wtedy istniało wiele zagrożeń dla rodziny, ale Biblia stawiała sprawę konkretnie: każdy, kto będzie próbował dokonać zamachu na miłość i ład w rodzinie, zostanie ukarany bardzo surowo.

Opisywany stan szczęścia pierwszych biblijnych osób był raczej propozycją Boga dla człowieka, niż czymś narzuconym - Bóg pozwolił ludziom wybrać pomiędzy dobrem a złem, a biblijny opis podkreśla przez to, że człowiek jest wolny w dokonywaniu swoich wyborów [Kijas 2004, 81-82]. Wskutek grzechu rajskiego natura ludzka została osłabiona i człowiek stał się zdolny do grzechu, który oddziałuje na wszystkie aspekty człowieczeństwa, również na zdolność do miłości i wierności. Nierozerwalność rodziny została ugodzona grzechem, stąd Mojżesz zezwolił mężowi napisać list rozwodowy odsyłający z domu żonę [Białkowska 2010].

W Piśmie Świętym bezżennymi mieli być ci, którzy służyli Bogu i narodowi. Zarówno wybór służby Jahwe czy miłość małżeńska wymagają wierności podjętej decyzji - realizowania powołania człowieka, które jest świadomym wyborem mężczyzny czy kobiety: „dlatego opuści mężczyzna swego ojca i swoją matkę, a złączy się z kobietą tak ściśle, że staną się jednym ciałem" (Rdz 2,24) [tamże].

W Starym Testamencie podkreślono, że rodzina powinna być otwarta na życie - potomstwo jest znakiem Bożego błogosławieństwa (Jr 18,21). 
„Mąż prawy zmierza do życia, kto zaś goni za grzechem - do śmierci” (Prz 11,19). Odpowiedzialność przed Bogiem i społeczeństwem za byt i życie religijne rodziny spoczywała na ojcu - głowie rodziny [Metzger i Coogan 1999, 688].

Prorocy wielokrotnie ukazują małżeństwo jako przymierze na wzór tego, jakie istnieje między Bogiem a ludzkością, co podkreśla, że jest ono uroczystą przysięgą o walorze religijnym, która obowiązuje kontrahentów aż do śmierci. Z czasem akcentowali oni bardziej duchowy niż jurydyczny walor małżeństwa i sprzeciwiali się rozwodom, gdyż uważali je za świętokradcze sprzeniewierzenie się świętemu przymierzu i wyrządzenie krzywdy współmałżonkowi [Pawlak 2001, 65-74].

Tematyka rodziny i małżeństwa jest obecna w Nowym Testamencie: w Ewangeliach, listach św. Pawła, czy pismach św. Jana. Wartość i doniosłość instytucji rodziny są podkreślane już na samym początku Ewangelii synoptycznych: Jezus Chrystus przychodzi na świat w małżeństwie Józefa i Maryi: „z narodzeniem Jezusa Chrystusa było tak. Po zaślubinach Jego Matki, Maryi, z Józefem, wpierw nim zamieszkali razem, znalazła się brzemienną za sprawą Ducha Świętego" (Mt 1,18).

Święty Marek (Mk 10,1-12; por. Łk 16,18) porusza kwestię nierozerwalności małżeństwa, którą przypomniał Jezus, gdy był pytany przez faryzeuszów o to, dlaczego Mojżesz zezwalał na rozwód. Mesjasz nie tylko wyjaśnił powód ustanowienia przez Mojżesza takiego prawa - ze względu na ludzką słabość - lecz również wskazał, że „na początku tak nie było”, pokazując pierwotny zamysł Boga względem rodziny [Białkowska 2010]. Wypowiedź Jezusa ma swój punkt kulminacyjny: podnosi małżeństwo do rangi sakramentu i definitywnie potwierdza zasadę jego nierozerwalności: „co Bóg złączył, człowiek niech nie rozdziela” (Mt 19,6; Mk 10,9). Małżeństwo pochodzi od Boga i trwa do śmierci jednego z małżonków. Sakramentalność małżeństwa rozciąga się na rodzinę, która stała się drogą zbawienia i uświęcenia oraz domowym Kościołem - miejscem spotkania rodziny z Bogiem ${ }^{4}$.

Nauka Jezusa była rewolucyjna w kontekście ówczesnych starożytnych kultur, gdyż głosiła równość w godności kobiety i mężczyzny w małżeństwie: „A Ja wam powiadam: Każdy, kto oddala swoją żonę - poza

${ }^{4}$ Por. https://ddasz.wordpress.com/2017/09/18/malzenstwo-i-rodzina-w-biblii/ [dostęp: 17.08.2020]. 
wypadkiem nierządu - naraża ja na cudzołóstwo, a kto by oddaloną wziął za żonę, dopuszcza się cudzołóstwa" (Mt 5,32; por. Mt 19,9; Mk 10,11-12). Ponadto Jezus nakazywał wzajemny szacunek w rodzinach: zarówno dzieci wobec rodziców, jak i rodziców wobec dzieci ${ }^{5}$.

Święty Paweł w Pierwszym Liście do Koryntian (1Kor 7,1-40) podkreślił całkowite i wzajemne oddanie się sobie małżonków: „żona nie rozporządza własnym ciałem, lecz jej mąż; podobnie też i mąż nie rozporządza własnym ciałem, ale żona" (1Kor 7,4). Apostoł wskazał, że każdy człowiek ma prawo do wyboru własnej drogi życia w zależności od powołania i darów od Boga: bezżeństwa lub małżeństwa. Święty Paweł przestrzega przed rozrywaniem rodzin, a jeśli separacja jest konieczna, to wówczas osoba nie może wstępować w nowy związek.

W Liście do Efezjan (Ef 5,21-6,9) małżeństwo i rodzinę porównano do związku Chrystusa z Kościołem. Święty Paweł wielokrotnie podkreślił rolę miłości małżeńskiej, szacunku, zgody w rodzinie i wzajemnej troski małżonków o siebie: „tajemnica to wielka, a ja mówię: w odniesieniu do Chrystusa i Kościoła. W końcu więc niechaj również każdy z was tak miłuje swoją żonę jak siebie samego. A żona niechaj ze czcią się odnosi do swojego męża" (Ef 5,32-33).

W Ewangelii Święty Jan w opisie wesela w Kanie Galilejskiej $(\mathrm{J} 2,12)$ przedstawił troskę Chrystusa o małżeństwo z uwagi na jego rolę $\mathrm{w}$ życiu Kościoła. Natomiast w Apokalipsie Święty Jan porównał wizję przyszłego Królestwa Bożego do radosnych uroczystości weselnych: „Weselmy się i radujmy, bo nadeszły Gody Baranka, a Jego Małżonka przystroiła się" (Ap 19,7). Biblijną problematykę rodziny i małżeństwa wieńczy eschatologiczna wizja Nowego Jeruzalem, które jest „przystrojone jak oblubienica zdobna w klejnoty dla swego męża” (Ap 21,2c) [Pawlak 2001, 65-74].

W Biblii człowiek jako korona Bożego stworzenia jest wolny: może założyć rodzinę, która od samego początku jest zamierzona przez Boga. Prawda ta daje nie tylko podstawy do zawierania przez wiernych małżeństw sakramentalnych, ale również pokazuje, że rodzina ma swoją szczególną wartość w życiu Kościoła i społeczeństwa, przez co należy się jej szacunek oraz zapewnienie jej środków prawnych do rozwoju.

\footnotetext{
5 Tamże.
} 


\section{SOBÓR WATYKAŃSKI II O RODZINIE}

Problematyka rodziny była wielokrotnie poruszana przez Ojców Soboru Watykańskiego II, co świadczy o tym, że ciągle reformujący się Kościół ma na uwadze kwestie rodziny, która jest podstawową komórką budującą społeczność kościelną oraz świecką: „rodzina, w której różne pokolenia spotykają się i pomagają sobie wzajemnie [...] jest fundamentem społeczeństwa"6.

Apostolstwo jest według Soboru jednym z zadań rodziny w Kościele, które uwidacznia się w przykładzie i świętości życia małżeńskiego oraz w jego nierozerwalności ${ }^{7}$. Sobór podkreślił, że droga uświęcania, która jest jednocześnie posłannictwem rodziny, realizuje się poprzez wzajemną miłość, a modlitwa czyni z rodziny domowe sanktuarium. Misja ta jest realizowana poprzez: kult liturgiczny, czyny miłosierdzia, popieranie sprawiedliwości społecznej, dobre uczynki względem potrzebujących (AA 9, 11).

Ojcowie soborowi podkreślili, że należy zabezpieczyć prawo małżonków do zrodzenia i wychowania potomstwa (GS 52). Obowiązek wychowania ciąży w pierwszym rzędzie na rodzinie, a dopiero później na państwie i instytucjach wspierających zadania wychowawcze. Dopiero, gdy rodzice nie dokładają wystarczających starań w wychowaniu swoich dzieci, wówczas na zasadzie pomocniczości - można przejmować obowiązki wychowawcze pamiętając o woli rodziców ${ }^{8}$. Odpowiednio ukształtowane sumienia, zmysł chrześcijański wiernych, ale też mądrość i doświadczenie, są wielką pomocą w dostrzeganiu i podnoszeniu wartości małżeństwa i rodziny w społeczeństwie (GS 52).

Sobór podkreślił również wolność rodziców w kwestii swobodnego wychowania religijnego i zachęcił władzę świecką, by dawała swobodę w zakresie wychowania i kształcenia dzieci, np. poprzez wybór szkół czy

\footnotetext{
${ }^{6}$ Sacrosanctum Concilium Oecumenicum Vaticanum II, Constitutio pastoralis de Ecclesia in mundo huius temporis Gaudium et spes (07.12.1965), AAS 58 (1966), s. 1025115 [dalej cyt.: GS]; tekst polski w: Sobór Watykański II, Konstytucje, dekrety, deklaracje. Tekst polski. Nowe tłumaczenie, Pallottinum, Poznań 2002, s. 526-606, nr 52.

${ }^{7}$ Tenże, Decretum de apostolatu laicorum Apostolicam actuositatem (18.11.1965), AAS 58 (1966), s. 837-64 [dalej cyt.: AA]; tekst polski w: Sobór Watykański II, Konstytucje, s. 377-401, nr 10.

8 Tenże, Declaratio de educatione christiana Gravissimum educationis (28.10.1965), AAS 58 (1966), s. 728-39 [dalej cyt.: GE]; tekst polski w: Sobór Watykański II, Konstytucje, s. 314-24, nr 3 .
} 
środków wychowawczych ${ }^{9}$. Do zadań władzy państwowej należy ochrona i popieranie rodziny, strzeżenie moralności publicznej oraz troska o dobry byt rodzin (GS 52).

Ojcowie Soboru dostrzegali również problemy, z jakimi borykają się rodziny: rozdźwięki w rodzinach, nierówności społeczne uwarunkowane demograficznie, gospodarczo, socjalnie, konflikty międzypokoleniowe, zmiany socjologiczne (GS 8). Uwłaczające godności rodziny są: wielożeństwo, „plaga rozwodów”, wolna miłość, egoizm, hedonizm, niedozwolone zabiegi przeciw poczęciu, problemy społeczne i demograficzne (GS 47).

W dokumentach soborowych zauważono, że szczęście społeczeństwa jest uzależnione od dobrej kondycji rodzin. Sobór docenia różne inicjatywy i formy pomocy rodzinie, by ta mogła żyć w miłości (GS 47). Dlatego też należy dostrzegać jej potrzeby i brać pod uwagę warunki mieszkaniowe, pracy i ubezpieczeń społecznych, podatki, ale też kierowanie procesem migracyjnym tak, by zapewnić rodzinom jedność i możliwość wychowywania potomstwa (AA 11).

Dzieci uświęcają siebie i rodziców przez miłość i posłuszeństwo, które wyrażane są $\mathrm{w}$ szacunku i wdzięczności za trud wychowania, wsparciu w trudach życia czy starości. Rodzina świadoma swojej autonomii nie powinna ograniczać się do własnych spraw, ale powinna dzielić się swoim bogactwem ludzkim i duchowym z innymi (GS 48).

Bardzo ważne miejsce ma rodzina we wspólnotach lokalnych, dlatego Sobór zachęca biskupów, proboszczów i wszystkich duszpasterzy, by aktywizowali rodziny i włączali je w życie parafialne czy ruchy religijne (AA 30).

Rodzice mają zadanie uczyć i wychowywać swoje dzieci już od najmłodszych lat do miłości Boga i drugiego człowieka. Nauka troszczenia się o bliźnich nie powinna ograniczać się do kwestii wrażliwości na potrzeby materialne, ale również ludzkie i duchowe (AA 30). Sobór nazywa rodzinę „pierwszą szkołą cnót społecznych, potrzebnych wszelkim społecznościom” (GE 3).

Młodzi powinni otrzymać odpowiednie wsparcie wiedzą i doświadczeniem od swoich bliskich. Jednocześnie Sobór podkreśla, że rodzina nie może wywierać presji i przymuszać do wstępowania w związek małżeński czy decydować o wyborze partnera (GS 52).

\footnotetext{
9 Tenże, Declaratio de libertata religiosa Dignitatis humanae (07.12.1965), AAS 58 (1966), s. 929-46; tekst polski w: Sobór Watykański II, Konstytucje, s. 410-21, nr 5.
} 
Sobór zauważa również wymiar misyjny i ekumeniczny rodziny chrześcijańskiej, która przez przykład prawdziwie chrześcijańskiego życia, praktykowanie i pielęgnowanie cnót, należyte wychowania dzieci w atmosferze szacunku i miłości, może przyciągnąć do Chrystusa ludzi niewierzących, innych religii czy skłonić do ponownej jedności braci odłączonych. Wierni powinni obserwować Kościół i starać się o odnowę tego, co wymaga zmian, by jaśniej dawać świadectwo światu (AA 11).

Małżonkowie, jako obraz miłości Chrystusa do Kościoła, są wezwani do tworzenia jedności i wierności rodziny na gruncie miłości, która jest otwarta na płodność (GS 48). Chrystus uświęca małżonków i ich zadania poprzez oddzielny sakrament, który „umacnia i jakby konserwuje małżonków chrześcijańskich do obowiązków i godności ich stanu" (GS 48).

Obowiązek przekazywania i pielęgnowania wiary spoczywa na rodzinach, które Sobór nazywa „domowym Kościołem”. Rodzice mają być pierwszymi głosicielami Ewangelii wobec swoich dzieci poprzez słowo i przykład. Zadaniem rodziców jest również przygotowanie dzieci do odkrycia swojego powołania, czy to małżeńskiego, czy duchownego.

\section{WYBRANE DOKUMENTY MAGISTERIUM KOŚCIOŁA DOTYCZĄCE RODZINY}

Posoborowe Magisterium Kościoła wielokrotnie podejmowało problematykę małżeństwa i rodziny, by lepiej ukazać ówczesnym ludziom prawdy zakorzenione w Biblii oraz wskazania Soboru Watykańskiego II. Część z tych wypowiedzi znalazła swoje implikacje w KPK/83. W niniejszym artykule nie sposób dokonać głębokiej analizy wszystkich tych dokumentów, więc należy wspomnieć o trzech z nich.

Papież Paweł VI w encyklice Humanae vitae ${ }^{10}$ podjął tematykę moralności życia małżeńskiego oraz przekazywania życia. Biskup Rzymu przypomniał i uwypuklił naukę Magisterium Kościoła m.in. odnośnie do: integralnej wizji człowieka, miłości małżeńskiej, odpowiedzialnego rodzicielstwa, kwestii stosunków małżeńskich i regulacji poczęć. Kardynał Karol Wojtyła w polskim opracowaniu tej encykliki podkreślił, że „tłumaczy ona,

\footnotetext{
${ }^{10}$ Paulus PP. VI, Litterae encyclicae de propagatione humanae prolis recte ordinanda Humanae vitae (25.07.1968), AAS 60 (1968), s. 481-503 [dalej cyt.: HV].
} 
że prawdziwa miłość małżeńska jest nieodłączna od obowiązku rodzicielstwa, że miłości takiej odpowiada rodzicielstwo świadome, natomiast nie godzi się z nią antykoncepcja"11.

Encyklika Humanae vitae została wydana, gdy w świecie panowały duże napięcia i spory dotyczące problematyki odpowiedzialnego rodzicielstwa. Papież Paweł VI oparł swoje nauczanie na prawie naturalnym oraz prawie ewangelicznym, które są wyrazem woli Bożej. W krakowskim komentarzu do encykliki czytamy: „Papieże przez prawo naturalne rozumieją obiektywny porządek moralny wypisany w rozumnej naturze człowieka, niezależny od prawa pozytywnego ustanowionego przez władzę państwową, stały i niezmienny, obejmujący wszystkich ludzi, zawierający nie tylko najogólniejsze idee i zasady moralne, ale też szczegółowe normy postępowania"12. Tak rozumiane prawo naturalne w nauczaniu Magisterium Kościoła jest czymś obiektywnym, zgodnym z naturą i rozumem ludzi.

Najgłębszą istotą małżeństwa jest płodne, miłosne zjednoczenie osób, które wyrasta z Bożego planu miłości: „małżonkowie poprzez wzajemne oddanie się sobie, im tylko właściwe i wyłączne, dążą do takiej wspólnoty osób, aby doskonaląc się w niej wzajemnie współpracować równocześnie z Bogiem w wydaniu na świat i wychowaniu nowych ludzi” (HV 8). Papież Paweł VI podkreślił przez to, że dążenie do doskonałości nie stoi w sprzeczności z powołaniem do rodzicielstwa, co podkreśla jej psychofizyczny charakter: zmysłowość (cielesność) i duchowość zarazem. Innymi cechami charakterystycznymi dla miłości małżeńskiej są: wierność i wyłączność, równość małżonków ${ }^{13}$.

Humanae viatae jako pierwszy dokument Magisterium Kościoła wprowadza pojęcie „odpowiedzialnego rodzicielstwa”, które sprawia, że „małżonkowie stają się wolnymi i odpowiedzialnymi współpracownikami BogaStwórcy” (HV 1). Przez takie pojęcie małżeństwa jasno widać, że nie jest ono przypadkiem czy skutkiem ślepych sił przyrody, a odpowiedzialność to nie tylko powstrzymywanie się od przekazywania życia w określonych przypadkach, ale również prokreacja, która jest w pełni ludzka, czyli

${ }^{11}$ Paweł VI, Encyklika Humanae vitae oraz komentarz teologów moralistów środowiska krakowskiego pod kierunkiem Karola kardynała Wojtyły (przedruk z: „Notificationes e curia Metropolitana Cracoviensi”, nr 1-4 A.D. 1969, s. 71-105), http://kodr.pl/ wp-content/uploads/2017/03/humanae_vitae.pdf [dostęp: 17.08.2020].

12 Tamże.

${ }^{13}$ Tamże. 
wolna i odpowiedzialna, a jako działanie rozsądne i rozważne, staje się realizacją Bożego powołania ${ }^{14}$.

Św. Paweł VI odrzuca: aborcję, szereg metod antykoncepcyjnych sprzecznych z nauką Kościoła, „bezpośrednie obezpłodnienie, czy to stałe, czy czasowe, zarówno mężczyzny, jak i kobiety" (HV 14). Jedynymi dozwolonymi metodami regulacji poczęć są całkowita wstrzemięźliwość lub wstrzemięźliwość w okresach płodnych, co jest zgodne z nauką Kościoła, która nigdy nie uzależniała wartości moralnej stosunku małżeńskiego od jego płodności ${ }^{15}$.

Kolejnym ważnym dokumentem, na który należy zwrócić uwagę jest adhortacja apostolska Jana Pawła II o zadaniach rodziny chrześcijańskiej w świecie współczesnym Familiaris consortio ${ }^{16}$, która w szczególności porusza zagadnienia: wspólnoty małżeńskiej i zadań rodziny jako Kościoła domowego. Papież podkreśla, że małżeństwo chrześcijańskie podlega przede wszystkim prawu Bożemu, gdyż instytucje te ustanowił Bóg jako trwałe przymierze pomiędzy mężczyzną a kobietą. Ponadto dla ochrzczonych jest ono zawsze sakramentem, w czym wyraża się misterium jedności i płodnej miłości, w którym małżonkowie wspierają się w życiu oraz przyjmują i wychowują potomstwo, by osiągnąć świętość [Dyduch 2016, 127-40].

Małżeństwo na mocy prawa naturalnego jest związkiem trwałym, który przed Soborem Watykańskim II nazywano „kontraktem”, jednak Sobór zastąpił je terminem „przymierze”, gdyż dotyczy ono relacji pomiędzy osobami, a jego gwarantem jest Bóg. Kontrakt dotyczy bardziej przedmiotów i można go zerwać, natomiast przymierze zawierane jest na zawsze. „Komunia miłości pomiędzy Bogiem i ludźmi, stanowiąca zasadniczą treść Objawienia i doświadczenia wiary Izraela, znajduje swój wymowny wyraz w przymierzu oblubieńczym zawartym między mężczyzną i kobietą" (FC 12), które „na mocy sakramentalnego charakteru małżeństwa wzajemny związek małżonków staje się bardziej nierozerwalny” (FC 13) [tamże].

Pierwszym i bezpośrednim skutkiem małżeństwa jest więź-wspólnota dwojga, co jest podstawą szerszej wspólnoty rodzinnej poprzez skierowanie ku zrodzeniu i wychowaniu dzieci. Rodzina ma być „służbą życiu”, gdyż

\footnotetext{
${ }^{14}$ Tamże

15 Tamże.

${ }^{16}$ Ioannes Paulus PP. II, Adhortatio apostolica de Familiae Christianae muneribus in mundo huius temporis Familiaris consortio (22.11.1981), AAS 74 (1982), s. 81-191 [dalej cyt.: FC].
} 
jest podstawowym źródłem dla nowego życia oraz ma być pierwszym obrońcą życia od poczęcia aż do naturalnej śmierci. Konsekwencją zrodzenia potomstwa jest obowiązek i prawo do wychowania dzieci. Władza państwowa oraz Kościół nie mogą naruszać integralności rodziny poprzez przekraczanie swoich kompetencji. Obowiązek i prawo wychowania potomstwa przez rodziców są zawsze pierwotne i uprzednie w stosunku do innych podmiotów, dlatego w normalnych warunkach nie mogą być one zawłaszczane i zastępowane [tamże].

Rodzina jest domowym Kościołem, gdyż „Kościół znajduje w rodzinie, zrodzonej z sakramentu, swoją kolebkę i miejsce, w którym wchodzi w pokolenia ludzkie, a one w Kościół" (FC 15). Ewangelizacja w rodzinie (ad intra) oraz ewangelizacja rodziny (ad extra) dokonuje się poprzez „Ewangelię wyrażoną głęboko życiem, przez co rodzina staje się głosicielką Ewangelii dla wielu rodzin oraz dla otoczenia, w którym żyje" (FC 52) ${ }^{17}$. Często w trudnych warunkach społecznych i politycznych (prześladowanie Kościoła, ustawy antyreligijne, laicyzm, obojętność religijna, brak wolności religijnej), to rodzina jest jedynym środowiskiem ewangelizacyjnym oraz jedynym świadkiem Ewangelii [tamże].

Papież Jan Paweł II zwrócił uwagę, że rodzina ma również wypełniać zadanie kapłańskie w komunii z całym Kościołem poprzez uświęcanie siebie i świata. Dzieje się to poprzez życie sakramentalne rodziny, co najpełniej uwidacznia się w Eucharystii. Ponadto ważne jest, aby rodzina była szkołą modlitwy prywatnej i liturgicznej oraz by prowadziła apostolstwo [tamże].

W adhortacji wyliczono również powody kryzysu, jaki dotyka małżeństwo i rodzinę, są to: małżeństwa na próbę, rzeczywiste wolne związki, katolicy żyjący tylko po ślubie cywilnym lub żyjący w separacji, rozwody. Jednak, mimo że sytuacje te są czymś nieprawidłowym, to nie można oceniać ich zawsze tak samo [tamże].

W 1983 r. w Rzymie została wydana Karta Praw Rodziny ${ }^{18}$ jako odpowiedź na Synod Biskupów z 1980 r. oraz adhortację apostolską Familiaris consortio (FC 46). W preambule Karty zaznaczono, że nie jest to dokument

\footnotetext{
${ }^{17}$ Zob. także Paulus PP. VI, Adhortatio apostolica de Evangelizatione in mundo huius temporis Evangelii nuntiandi (08.12.1975), AAS 58 (1976), s. 5-76, nr 71.

${ }^{18}$ Carta dei Dirtti della Famiglia presentata dalla Sante Sede a tutte le persone, istituzioni ed autorita ed autorita interessate alla missione della famiglia nel mondo di oggi (22.10.1983), „Communicationes” 15 (1983), nr 2, s. 140-52.
} 
wiążący prawnie, ani nie jest on wykładem dogmatycznym - raczej miał on na celu zebranie $\mathrm{z}$ różnych źródeł i przedstawienie światu (nie tylko chrześcijanom) praw, jakie przynależą instytucji rodziny. Dokument ten składa się z 12 artykułów, które w swoich podpunktach wyrażają głęboką humanistyczną wizję rodziny, która jest naturalnym bytem społecznym.

\section{KODEKS PRAWA KANONICZNEGO Z 1983 ROKU W OBRONIE RODZINY}

W KPK/83 naczelną zasadą są słowa salus animarum suprema lex, czyli zbawienie dusz jest najwyższym prawem. Jedną z dróg do zbawienia jest wybór powołania do życia w małżeństwie i w rodzinie. Prawa wiernych do tego wyboru pomagają zabezpieczyć normy KPK/83: począwszy od urodzenia się dziecka i kształtowania osobowości człowieka aż po dokonywany wybór drogi życiowej.

W Księdze II „Lud Boży”, Tytule I „Obowiązki i prawa wszystkich wiernych" należy zauważyć, że przedstawiono podstawowe obowiązki i prawa wiernych: równość w godności i działaniu oraz obowiązek dążenia do świętości w odpowiedni sposób do swojego stanu czy pozycji w Kościele (kan. 208; 210); obowiązek współpracy w dziełach Kościoła i zachowywania Jego nauczania (kan. 211-212); prawo do korzystania z pomocy i dóbr duchowych Kościoła (kan. 213). Prawo do chrześcijańskiego wychowania oraz inne podstawowe prawa wspólne wszystkim wiernym w Kościele dają solidny fundament do osiągnięcia dojrzałości ludzkiej, która niezbędna jest, aby świadomie wybrać życie w małżeństwie i założyć rodzinę (kan. 217). Kościół zabezpiecza te prawa, również u dzieci wskazując, że poza szczególnymi wypadkami w imieniu małoletnich oraz „pozbawionych używania rozumu" działają prawni opiekunowie, w pierwszym rzędzie rodzice (kan. 98), którzy mają obowiązek wychowywania potomstwa w zgodzie z nauką Kościoła, przez co przyczyniają się do budowania Ludu Bożego (kan. 226; 774).

Ustawodawca kodeksowy zaznacza, że „wszyscy wierni mają prawo być wolni od jakiegokolwiek przymusu w wyborze stanu życia” (kan. 219), co obejmuje nie tylko zakaz stosowania środków represji, szantażu czy przymusu, ale również to, że np. prawo do zawarcia małżeństwa (ius connubii) nie może być w niesprawiedliwy sposób ograniczane. Warto podkreślić, że ten kanon został tak sformułowany, by nie pozostawiać wątpliwości, że 
nikt nie może domagać się zawarcia małżeństwa wbrew woli drugiej osoby, czy też rościć sobie prawa do święceń czy przyjęcia do instytutu zakonnego. Kanon ten zasługuje na szczególną uwagę ze względu na tematykę niniejszego artykułu, gdyż obrona praw w rodzinie rozciąga się na różne aspekty ludzkiego życia. Praktyka sądowa pokazuje, że nadal zdarzają się przypadki przymuszania do zawierania małżeństwa, co jest sprzeczne $\mathrm{z}$ wolą ustawodawcy kościelnego oraz uderza w godność człowieka [Hervada 2011a, 212].

Postulat soborowy o dawaniu świadectwa i apostolstwie rodzin znalazł urzeczywistnienie w kan. 225, który został wzmocniony kan. 226: „żyjący $\mathrm{w}$ stanie małżeńskim zgodnie $\mathrm{z}$ własnym powołaniem, mają szczególny obowiązek przyczyniać się do budowania Ludu Bożego przez małżeństwo i rodzinę". Sakramentalność małżeństwa sprawia, że złączenie kobiety i mężczyzny z Chrystusem wzywa ich nie tylko w sensie biologicznym do posiadania własnego potomstwa, ale również w znaczeniu nadprzyrodzonym: mają powiększać Rodzinę Bożą poprzez życie wiarą, przekazywanie jej, strzeżenie oraz promieniowanie nią w swoich społecznościach [Tenże 2011b, 217].

Rodziny powinny wspierać swoich bliskich poprzez radę, rozmowy, dzielić się doświadczeniem życiowym w wyborze stanu życia - również duchownego (kan. 233). Ustawodawca w KPK/83 zaznacza, że wierni żyjący w rodzinach mogą angażować się w posługiwanie w Kościele. Mężczyzna może pełnić funkcje akolity lub lektora (kan. 230), czy też może zostać diakonem stałym (kan. 236). Takim osobom (pod pewnymi warunkami) należy się wynagrodzenie, by mogli zadośćuczynić potrzebom materialnym swoich rodzin (kan. 231; 281). Wierni świeccy, chcący jeszcze pełniej włączyć się w misję apostolatu i uświęcania świata, mogą wstępować do instytutów świeckich życia konsekrowanego (kan. 710) i żyć w rodzinach w zwyczajnych warunkach świata (kan. 714). Wierni świeccy mają prawo zasiadać $\mathrm{w}$ radzie duszpasterskiej, by wspierać biskupa w pełnieniu jego mandatu. Skład osobowy tej rady ma odzwierciedlać całą porcję Ludu Bożego. To właśnie rodziny są przeważającą częścią Kościoła i powinny znaleźć się w tej radzie, by troszczyć się o swoje potrzeby [Sitarz 2005, 406].

Proboszcz powinien troszczyć się o życie duchowe powierzonych sobie wiernych, zwłaszcza rodzin - powinien być blisko nich, odwiedzać je, uczestniczyć w ich troskach, dbać o to, by wzrastało i rozwijało się ich życie chrześcijańskie, wspierać małżonków i rodziców w wypełnianiu ich 
zadań (kan. 528-529). Proboszcz winien „popierać i umacniać zadanie rodziców w zakresie katechezy rodzinnej" (kan. 776), do której zobowiązani są rodzice, a także ci, którzy zastępują ich oraz chrzestni (kan. 774). W przepowiadaniu słowa Bożego nie powinno zabraknąć nauki „o jedności i trwałości rodziny oraz o jej zadaniach" (kan. 768).

W KPK/83 w Księdze III „Nauczycielskie zadanie Kościoła”, Tytule III „Wychowanie katolickie” ustawodawca przypomina naturalne prawo rodziców do wychowywania swojego potomstwa i zaznacza, że wierni mają obowiązek i prawo doboru najstosowniejszych do okoliczności miejsca i czasu metod wychowawczych, by zapewnić dziecku katolickie wychowanie, a społeczność świecka powinna pomagać im w wychowaniu dzieci według swoich wartości (kan. 793). Kanon ten jest zgodny z nauką Soboru Watykańskiego II oraz deklaracją o wychowaniu chrześcijańskim Gravissimum educationis ( $\mathrm{nr}$ 6). Podobne regulacje dotyczące wolności w zakresie wychowania własnego potomstwa znajdują się $\mathrm{w}$ dokumentach międzynarodowych, np. w Powszechnej Deklaracji Praw Człowieka wydanej przez ONZ 10 grudnia 1948 r. [González del Valle 2011, 609-10].

Kościół z mandatu Bożego powinien wspierać rodzinę w wychowaniu dzieci i przekazywaniu wartości chrześcijańskich (kan. 794-795). Do zadań Kościoła (w wymiarze powszechnym i lokalnym) należy popieranie wychowania religijnego i moralnego w szkołach poprzez domaganie się wolności w wychowaniu religijnym, co zapewniane jest przez odpowiednie ustawy państwowe. Kościół ma prawo zakładać szkoły i uniwersytety katolickie oraz kierować nimi. Wierni powinni wspierać te inicjatywy, gdyż są one wsparciem dla rodzin i zabezpieczeniem ich praw, z czego rodziny powinny chętnie korzystać (kan. 796-814).

Ustawodawca kodeksowy przypomina, że małżonkowie i rodzice uczestniczą w uświęcającym zadaniu Kościoła poprzez życie liturgią Kościoła (zwłaszcza Eucharystią), która przenika ich codzienność i katolickie wychowanie potomstwa (kan. $835 \S 3$ ), co Jan Paweł II określił „przemianą całego życia małżeńskiego w nieustanną ofiarę duchową" (FC 56). Zadanie uświęcania należy również do rodziców, którzy są pierwszymi wychowawcami swoich dzieci [Krzywda 2011, 18].

$\mathrm{W}$ powołaniu do uświęcania siebie i swojego potomstwa rodzice są obdarowywani przez Kościół pomocą sakramentalną. Rodziny przed przystąpieniem do sakramentów mają być odpowiednio przygotowane i wspierane troską duszpasterską, np. przed ochrzczeniem swojego potomstwa 
(kan. 851 § 2). To na rodzicach ciąży obowiązek ochrzczenia dzieci bez niepotrzebnego odkładania tego w czasie (kan. 867), a miejscem chrztu powinien być kościół parafialny rodziców dziecka (kan. 857 § 2). W odniesieniu do imienia nadawanego na chrzcie ustawodawca kościelny zaleca, by było ono zgodne $\mathrm{z}$ duchem chrześcijańskim (kan. 855). Przyjęcie chrztu przez dziecko nie może być aktem bezmyślnym, umotywowanym tylko tradycją rodzinną czy uwarunkowaniami społecznymi. Niegodziwy jest chrzest udzielany wbrew woli rodziców (chyba że w niebezpieczeństwie śmierci). Ustawodawca kodeksowy stanowi na temat odłożenia chrztu w czasie w przypadku, gdy dziecko miałoby nie mieć możliwości wychowywania w duchu katolickim (kan. 868). Takie unormowanie kwestii związanych chrztem ma wspomóc rodzinę $\mathrm{w}$ świadomym, katolickim wychowaniu potomstwa, a dziecko zabezpieczyć przed sytuacją, którą piętnował Jezus w odniesieniu do faryzeuszów: „Wiążą ciężary wielkie i nie do uniesienia i kładą je ludziom na ramiona, lecz sami palcem ruszyć ich nie chcą. Wszystkie swe uczynki spełniają w tym celu, żeby się ludziom pokazać" (Mt 23,4-5a). Sakramenty mają być dla rodzin autentycznym umocnieniem i świadomym przeżyciem - są środkami zbawienia. Kościół podkreśla ponadto, że chrzestni wybierani przez rodziców dziecka mają być dla nich i dla dziecka wsparciem, pomocą w chrześcijańskim wtajemniczeniu oraz katolickim wychowaniu, stąd chrzestnym KPK/83 stawia wymagania i nakłada na nich obowiązki (kan. 872-874).

Wspieranie dziecka w rozwoju duchowym jest obowiązkiem rodziców we współpracy z duszpasterzami. Warto przytoczyć tu słowa adhortacji apostolskiej Benedykta XVI Sacramentum caritatis ${ }^{19}$ : „na drodze wtajemniczenia należy zawsze angażować rodzinę. Przyjęcie Chrztu, Bierzmowania i przystąpienie po raz pierwszy do Eucharystii są momentami decydującymi nie tylko dla osoby, która przyjmuje te sakramenty, ale również dla całej rodziny" (nr 19). Ustawodawca w kan. 890 podkreśla rolę rodziców w przygotowaniu do sakramentu bierzmowania, a w kan. 914 troskę rodziców o przystąpienie swoich dzieci do Stołu Pańskiego. Pierwszeństwo woli rodziców w wychowaniu chrześcijańskim swojego potomstwa jest podkreślone również $\mathrm{w}$ przypadku chęci zawarcia małżeństwa przez małoletnich - Kościół wymaga specjalnej zgody ordynariusza, gdy

${ }^{19}$ Benedictus PP. XVI, Adhortatio apostolica postsynodalis de Eucharistia vitae missionisque Ecclesiae fonte et culmine Sacramentum caritatis (22.02.2007), AAS 99 (2007), s. 143-80. 
rodzice małoletnich nupturientów w uzasadniony sposób sprzeciwiają się takiemu małżeństwu. Jednak należy podkreślić, że sprzeciw ten nie przekreśla możliwości zawarcia małżeństwa w takim przypadku, ale wymaga zezwolenia kompetentnego przełożonego kościelnego (kan. $1071 \S 1,6^{\circ}$ ).

Wielokrotnie ustawodawca w KPK/83 podkreśla udział wspólnoty parafialnej i duszpasterzy w życiu religijnym rodzin. Wymiar społeczny i wspólnotowy rodzin, które żyją Ewangelią jest nie do zastąpienia. Pomoc, jaką otrzymują rodziny od Kościoła, ukierunkowana jest przede wszystkim na osobiste uświęcanie małżonków: „ażeby wiernie zachowując i chroniąc przymierze małżeńskie osiągali w rodzinie życie coraz bardziej święte i doskonałe" (kan. 1063, $4^{\circ}$ ).

Ustawodawca kościelny zagwarantował pomoc rodzinom, które wywodzą się z małżeństw mieszanych i podkreśla, że przedmiotem duszpasterskiej troski powinno być wsparcie takich rodzin $\mathrm{w}$ utrwalaniu $\mathrm{w}$ nich jedności oraz trwałości małżeństwa (kan. 1128).

Obrona jedności rodziny jest rzeczą bardzo poważną, na którą ustawodawca zwrócił również uwagę w sytuacjach trudnych w życiu małżeńskim i rodzinnym, np. zachęca małżonka, aby miał na uwadze dobro rodziny, tj. nawet $\mathrm{w}$ sytuacji zdrady, aby przebaczył drugiej stronie, a nie uciekał do separacji. Kodeks nie bagatelizuje powagi takiej sytuacji i podkreśla, że jest to czyn niesprawiedliwy i krzywdzący wobec niewinnego współmałżonka i rodziny (kan. 1152). Separacja małżonków jest przerwaniem pożycia i mimo, że godzi w jedność rodziny, to w określonych sytuacjach może być koniecznością, na którą zgodę powinna wydać władza kościelna - dzieje się tak w przypadku, gdy jedno z małżonków stanowi zagrożenie (w sensie duchowym lub fizycznym) dla drugiego lub potomstwa (kan. $1153 \S 1$ ).

Więzi rodzinne są jednym $\mathrm{z}$ najistotniejszych elementów budujących rodzinę. Również pamięć o tradycjach rodzinnych i przodkach jest doceniona przez KPK/83, który zezwala na posiadanie rodzinnego grobowca czy cmentarza, który za zgodą ordynariusza miejsca może zostać pobłogosławiony. Zgoda ordynariusza jest konieczna, gdyż pobłogosławiony cmentarz prywatny staje się miejscem świętym, które musi spełniać normy prawa państwowego (kan. 1241) [Martín de Agar 2011, 919-20].

W zarządzaniu dobrami duchowymi Kościoła ważny, a czasami i nie do zastąpienia, jest udział wiernych świeckich żyjących w rodzinach. Kodeks nakazuje takim osobom wypłacać sprawiedliwe i słuszne wynagro- 
dzenie, które umożliwi zaspokojenie potrzeb własnych oraz rodzinnych (kan. 1286 § 2).

Karą cenzury lub inną sprawiedliwą karą ekspiacyjną, po sprawiedliwym osądzie sędziego, należy ukarać rodziców lub osoby zastępujące ich, którzy oddają swoje dzieci do chrztu lub na wychowanie do religii niekatolickiej. Ustawodawca klasyfikuje to jako przestępstwo, jednak trzeba zwrócić uwagę na fakt, że literatura podkreśla, że chodzi tutaj o wychowanie dziecka, czyli jego całościową formację osobową. Znamion przestępstwa nie wyczerpuje sytuacja, w której dziecko pobiera naukę w szkole niekatolickiej. Ustawodawca miał tu na myśli celowe, świadome działanie, które uchybiałoby obowiązkom wychowania dzieci według wartości chrześcijańskich i katolickich (kan. 1366) [Arias 2011, 1025-1026].

W sądach kościelnych to rodzice winni reprezentować swoje małoletnie lub pozbawione używania rozumu dzieci. Ustawodawca kodeksowy zastrzega jednak, że w przypadku konfliktu interesów pomiędzy rodzicami i ich dziećmi, należy wyznaczyć dzieciom opiekuna lub kuratora. Po ukończeniu 14 roku życia (pod warunkiem osiągnięcia używania rozumu) małoletni mogą sami występować przed sądem w przypadku spraw duchowych (nawet wbrew woli rodziców), a przed ukończeniem 14 roku życia mogą to robić przy pomocy wyznaczonego przez sędziego kuratora (kan. 1478).

\section{ZAKOŃCZENIE}

Ustawodawca w KPK/83 postrzega rodzinę jako instytucję Bosko-ludzką, której podstawą jest sakramentalne małżeństwo kobiety i mężczyzny. Biblijna wizja małżeństwa i rodziny oraz postulaty Soboru Watykańskiego II i dokumentów Magisterium Kościoła znalazły swoje odzwierciedlenie w KPK/83. Kodeks zabezpiecza i chroni podstawowe prawa rodziny (np. do posiadania potomstwa i wychowywania go zgodnie z wiarą katolicką), ale również przypomina o obowiązkach rodzin względem Kościoła i społeczności ludzkiej (np. dawanie świadectwa życia chrześcijańskiego i apostolat). Ustawodawca kościelny przypomina również duszpasterzom oraz instytucjom kościelnym i świeckim o konieczności wspierania rodzin w ich troskach i prawidłowym funkcjonowaniu, gdyż prawidłowo funkcjonujące rodziny są podstawą ładu społecznego i kościelnego. 
Pomimo tego, że od promulgowania KPK/83 minęło prawie 40 lat, to kanony te zachowują swoją aktualność, czego wyrazem są kolejne dokumenty Kościoła i synody poświęcone tematyce rodziny.

\section{PIŚMIENNICTWO}

Arias, Juan. 2011. „Przestępstwa przeciwko religii i jedności Kościoła.” W Codex Iuris Canonici. Kodeks Prawa Kanonicznego. Komentarz. Powszechne i partykularne ustawodawstwo Kościoła katolickiego. Podstawowe akty polskiego prawa wyznaniowego. Edycja polska na podstawie wydania hiszpańskiego, red. Piotr Majer, 1024-1027. Kraków: Wolters Kluwer Polska.

Białkowska, Monika. 2010. „Rodzina w Biblii.” https://www.przewodnik-katolicki.pl/ Archiwum/2010/Przewodnik-Katolicki-18-2010/Wiara-i-Kosciol/Rodzina-w-Biblii [dostęp: 17.08.2020].

Dyduch, Jan M. 2016. „Wiodące idee adhortacji apostolskiej «Familiaris consortio».” Polonia Sacra 20, nr 1 (42):127-40.

González del Valle, José María. 2011. „Wychowanie katolickie.” W Codex Iuris Canonici. Kodeks Prawa Kanonicznego. Komentarz. Powszechne i partykularne ustawodawstwo Kościoła katolickiego. Podstawowe akty polskiego prawa wyznaniowego. Edycja polska na podstawie wydania hiszpańskiego, red. Piotr Majer, 609-28. Kraków: Wolters Kluwer Polska.

Hervada, Javier. 2011a. „Obowiązki i prawa wszystkich wiernych.” W Codex Iuris Canonici. Kodeks Prawa Kanonicznego. Komentarz. Powszechne i partykularne ustawodawstwo Kościoła katolickiego. Podstawowe akty polskiego prawa wyznaniowego. Edycja polska na podstawie wydania hiszpańskiego, red. Piotr Majer, 205-14. Kraków: Wolters Kluwer Polska.

Hervada, Javier. 2011b. „Obowiązki i prawa wiernych świeckich.” W Codex Iuris Canonici. Kodeks Prawa Kanonicznego. Komentarz. Powszechne i partykularne ustawodawstwo Kościoła katolickiego. Podstawowe akty polskiego prawa wyznaniowego. Edycja polska na podstawie wydania hiszpańskiego, red. Piotr Majer, 215-22. Kraków: Wolters Kluwer Polska.

Jelonek, Tomasz. 2007. Matżeństwo i rodzina w Piśmie Świętym. Kraków: Wydawnictwo św. Stanisława BM Archidiecezji Krakowskiej.

Jelonek, Tomasz. 2011. Teologia biblijna. Kraków: Petrus.

Kijas, Zdzisław. 2004. Poczq̨tki świata i człowieka. Kraków: WAM.

Krzywda, Józef 2011. „Część I. Sakramenty.” W Komentarz do Kodeksu Prawa Kanonicznego. T. III/2: Księga IV. Uświęcajace zadanie Kościoła. Część I. Sakramenty. Część II. Pozostałe akty kultu Bożego. Część III. Miejsca i czasy święte, red. Józef Krukowski, 17-18. Poznań: Pallottinum.

Martín de Agar, José Tomás. 2011. „Cmentarze.” W Codex Iuris Canonici. Kodeks Prawa Kanonicznego. Komentarz. Powszechne i partykularne ustawodawstwo Kościoła katolickiego. Podstawowe akty polskiego prawa wyznaniowego. Edycja polska na podstawie wydania hiszpańskiego, red. Piotr Majer, 918-20. Kraków: Wolters Kluwer Polska.

Metzger, Bruce, i Michael Coogan, red. 1999. Słownik Wiedzy Biblijnej. Warszawa: Vocatio. 
Pawlak, Leonard. 2001. „Małżeństwo i rodzina w Biblii.” Studia nad Rodzina 1:65-74. Sitarz, Mirosław. 2005. „Rada duszpasterska.” W Komentarz do Kodeksu Prawa Kanonicznego. T. II/1: Księga II. Lud Boży. Część I. Wierni chrześcijanie. Część II. Ustrój hierarchiczny Kościoła, red. Józef Krukowski, 404-409. Poznań: Pallottinum. Stachowiak, Lech. 1990. Wstęp do Starego Testamentu. Poznań: Pallottinum.

\section{Obrona rodziny w Kodeksie Prawa Kanonicznego z 1983 roku}

\section{Streszczenie}

Artykuł podejmuje problematykę rodziny w Kodeksie Prawa Kanonicznego z 1983 r. W kontekście ataków, jakich instytucja rodziny doświadcza w ostatnich miesiącach, zwrócono uwagę na podstawy teologiczne, które znalazły swoje odzwierciedlenie w prawie kościelnym. Pierwszym źródłem jest Biblia, która ukazuje człowieka stworzonego przez Boga, jako istotę wolną, która może dokonywać wyborów. Rodzina jest w Piśmie Świętym ukazana jako instytucja naturalna, bezpośrednio zamierzona przez Boga. Jezus umacnia rodzinę poprzez sakrament małżeństwa. Sobór Watykański II w wielu swoich dokumentach poruszył kwestię rodziny i wskazał, że ma ona bardzo istotne zadania w Kościele i świecie, m.in. misyjność rodziny i apostolat.

Kodeks Prawa Kanonicznego z 1983 r. zabezpiecza liczne prawa i przypomina o obowiązkach rodziny. Bazując na prawie naturalnym i Bożym Objawieniu, ustawodawca kościelny podkreślił prawo do wychowywania potomstwa zgodnie z wiarą oraz nałożył obowiązek kształtowania osobowości człowieka w duchu chrześcijańskim. Kodeks podkreśla, że rodzina ma prawo do uzyskiwania pomocy od duszpasterzy i innych instytucji wspierających rodzinę. Ponadto wskazuje na obowiązki i prawa rodziny do uczestniczenia w życiu i misji Kościoła.

Słowa kluczowe: prawo kanoniczne; małżeństwo; rodzina; prawa i obowiązki

\section{Protection of the Family in the 1983 Code of the Canon Law}

\section{Summary}

This study explores the issue of the family in the 1983 Code of Canon Law. In the context of the attacks that the institution of the family has been experiencing in recent months, the attention has been paid to its theological bases in canon law. The Bible is the first source that set forth a man created by God who is able to make a decision in order to build a family. While the family is the foundational institution of society ordained by God. Jesus elevated the natural institution of marriage to the dignity of a sacrament. The Second Vatican Council in many of its documents raised the issue of the family and indicated that it has very important tasks in the Church and the world, including family mission and apostolate.

The 1983 Code of Canon Law secures numerous rights and reminds you of family responsibilities. Based on the natural law and divine revelation, the Church legislator emphasized the right to raise children in accordance with faith and imposed the obligation to shape the human personality in the Christian spirit. The Code highlights 
that the family has the right to obtain help from pastors and other institutions supporting the family. Furthermore, it indicates the duties and rights of the family to participate in the life and mission of the Church.

Key words: canon law; marriage; family; rights and obligations

Information about Author: KaRol MAFA-KARLIŃSKI, J.C.L., Ph.D. STUdENT - Faculty of Theology, the Pontifical University of John Paul II in Kraków; e-mail: karlinski karol@gmail.com; https://orcid.org/0000-0002-1549-5718 